\title{
Determination of the level of contamination of Well Water in phase III of Sharada Industrial Area Kano, Nigeria.
}

\author{
${ }^{1}$ Umar, A., ${ }^{2}$ Mohammad, Y. \\ ${ }^{1}$ School of Technology, Kano State Polytechnic, Kano, Nigeria. \\ ${ }^{2}$ Chemistry Department, Nigeria Defense Academy, Nigeria.
}

\begin{abstract}
The presence of industrial activities in Sharada Industrial Estate in Kano city promoted the motive behind those studies. Hence the present study was undertaken to characterize the physicochemical parameters of well water in phase III of Sharada Industrial Estate by randomly taking Well water sample from five different locations. Evaluation of Physicochemical parameters was carried out and the result for $\mathrm{pH} 8.15$ was least in sample $S_{A}$ and 9.15 in sample $S_{B}$. Conductivity was least in sample $S_{D}(0.25)$ and highest in sample $S C(0.32)$. Total dissolved solids $(\mathrm{mg} / \mathrm{l})$ wereleast in sample $S_{B}$ and $200 \mathrm{mg} / \mathrm{l}$ in sample $S_{D}$. TSS value of $20 \mathrm{mg} / \mathrm{l}$ and $100 \mathrm{mg} / \mathrm{l}$ was found in samples $S_{B}$ and $S_{D}$ respectively. TH of $48 \mathrm{mg} / \mathrm{l}$ and 1088 was detected in samples $S_{B}$ and $S_{A}$. The $B O D$ for the sample was all within 0.60 and $0.70 . C O D(\mathrm{mg} / \mathrm{l})$ in sample $S_{D}$ was 1.60 and highest in sample $S C$, 51.60. For Nitrate, the least $1.90 \mathrm{mg} / \mathrm{l}$ in sample $S_{D}$ and highest, 15.70 in sample $S_{B}$. Compared to the World Health Organization and other recognized agencies, the result showed that the parameters are within tolerable limits.
\end{abstract}

Keywords: Well water, Sharada industries,

\section{Introduction}

Water is a chemical substance with the chemical formula $\mathrm{H}_{2} \mathrm{O}$. Water molecules contain oxygen and two hydrogen atoms connected by covalent bonds. Water is a liquid at ambient condition, but it often co-exist on earth with its solid state, ice and gaseous state (water vapor or steam). Under nomenclature used to name chemical compounds, hydrogen monoxide is the scientific name for water though it is almost never used.

Water covers $70 \%$ of the earth surface and is vital for all known form of life. On earth, $96.5 \%$ of the planets water is found in ocean, $1.7 \%$ in ground water, $1.7 \%$ in glaciers and the ice caps Antarctica and Greenland, a small fraction in other large water bodies, and $0.001 \%$ in the air as vapor. Only $25 \%$ of earth's water is fresh water and $98.8 \%$ of that water is in ice and ground water. Less than $0.3 \%$ of all fresh water in rivers, lakes and atmosphere, and even smaller amount of the earth's fresh water $0.003 \%$ is contained within biological bodies and manufactured products ${ }^{4}$.

Water on earth moves continually through a hydrological cycle of evaporation and transpiration. Safe drinking water is essential to human and other life forms. Access to safe drinking water has improved over the last decades in almost every part of the world, but approximately one billion people still lack access to safe water and over 2.5 billion lack access to adequate sanitation. There is clear correlation between access to safe water and GDP per capital. However, observers have observe that by 2025 more than half of the world population will be facing water-based vulnerability. A recent report suggests that by 2030 in some developing regions of the world, water demand will exceed supply by $50 \%{ }^{5}$.

Water plays an important role in the world economy as it functions as a solvent for a wide variety of chemical substances and facilitates industrial cooling and transportation. Approximately $70 \%$ of the fresh water used by humans goes to agriculture ${ }^{6}$.

\section{Sources of Water}

The sources of water are many but the main ones being surface water and ground water. Typical examples of surface water include spring, shallow and deep well, boreholesetc. ${ }^{2}$.

\section{Ground Water}

Ground water is the water held within the interconnected openings of saturated rock beneath the land's surface. The constant movement of this water is often called the "hydrologic cycle". The cycle demonstrates three basic types of activities; inflow, outflow and storage. An inflow is an increase to part of the hydraulic cycle, while an outflow is a removal of water. The term retention refers to the retention of water by a particular part of the system. Well is among the places where ground water can easily be found. It is defined as a hole or shaft, usually vertical, excavated in the earth for bringing ground water to the surface. It may be shallow or deep depending on the depth before the water can be reached ${ }^{8}$. 
Well water can vary greatly in depth, water volume, and water quality. Well typically contains more minerals in solution than surface water and may require treatment to soften the water by removing minerals such as arsenic, iron manganese. Hand dug Wells are excavations with diameters large enough to accommodate one or more men with shovels digging down to below the water level. They can be lined with laid stones or bricks: extending the lining upward above the ground surface to form a wall around the Well, which serves to reduce both contamination and injuries by falling into the Well. More modern methods now uses reinforced concrete or plain concrete pre-cast wall rings that are lowered into the hole ${ }^{3}$.

\section{Ground water contamination.}

The quality of ground water can be affected by both natural and anthropogenic activities in aquifers unaffected by human activities. In addition to natural sources quality can be affected by agricultural, municipal and industrial activities in the recharge zone of the aquifer ${ }^{8}$. Addition of unwanted or undesirable substances left on the ground caused by human activities spreads the effects far beyond the site of the original contamination?

Residential sources of contamination outflow from improperly functioning sewage system are a major cause of contamination. These contaminants include bacteria, viruses, nitrates, and organic compounds ${ }^{7}$. Improper storage or disposal of household products such as paints, synthetics, detergents, solvents, oil, pool chemicals, pesticides, bacteria, gasoline and diesel fuel may also result in ground water contamination. If such chemicals are stored in basements or garages with the floor drains, spillage may introduce these chemicals into ground water.

Agricultural source of contamination; ground water contamination may stem from agricultural activities. Fertilizers, pesticides, herbicides, and animal waste all pose potential threat to ground water quality. Fields with over applied or misapplied chemical may introduce contaminants such as organic compounds, excess nitrogen, cadmium, chloride, mercury and selenium into the ground water. Runoff from animal waste may result in nitrate, coli form bacteria, and sulphate contamination?

\section{Material And Methods}

All reagents used in carrying out this analysis are of analytical grade. The samples studied were collected from five different Wells located in phase III of Sharada Industrial area. The parameters analyzed are $\mathrm{pH}$, Color, odor, taste, conductivity, suspended solid, dissolved solid, total hardness, COD, BOD, dissolved oxygen, nitrate and lead. The precise locations where the samples were collected are. The rubber containers (Guga in Hausa) used in fetching water from the Wells was used directly and in exactly the same way they were used without any pre-treatment. The Wells were well stirred with the collecting vessels before the samples were finally collected and drawn up. The sampling bottles (plastic) were filled and taken to the laboratory for some series of analysis.

Table 1: Sampling locations

\begin{tabular}{|l|l|l|l|}
\hline Sample & Location & Time & Date \\
\hline A & Mundadu & $9: 00 \mathrm{am}$ & $02 / 04 / 2012$ \\
B & Yan Tagwaye & $9: 30 \mathrm{am}$ & $02 / 04 / 2012$ \\
C & LayinGidanRodi & $10: 00 \mathrm{am}$ & $02 / 04 / 2012$ \\
D & LayinDangote & $10: 30 \mathrm{am}$ & $02 / 04 / 2012$ \\
E & Tsamiya & $10: 45 \mathrm{am}$ & $02 / 04 / 2012$
\end{tabular}

\section{Result And Discussion}

The results of the Physical and chemical parameters are summarized in tables 1 and 2 below.

Colorsin samples were absent with exception of sample D that was found to be slightly brownish (dusty) in appearance. This can be attributed to the high concentration of suspended solid in the sample. The recommended value for color in portable water recommended by WHO, ISI and BSI are 5 hozens. The result obtained for

Odor in all samples showed that none of them has odor. The odor if present could not be determined by mere smelling until the samples were boiled in a water bath to a temperature of about 50 to $600 \mathrm{C}$. Water with bad odor may contain certain concentration of volatile organic compounds.

Taste: Except for sample E that tasted slightly salty, none of the other samples was found to posses any detectable unusual taste. The salty samples could be an indication of the presence of slight concentration of chloride, which imparts a salty taste in water.

pHis an important ecological factor and provides an important piece of information in much geochemical equilibrium. It is an important parameter in water body since most of the aquatic organisms are adapted to an average $\mathrm{pH}$ and do not withstand abrupt changes. From the result obtained, the $\mathrm{pH}$ of the samples ranged from a 
minimum of 8.45 to a maximum of 9.15 . These values fall within the highest desirable limit (HDL) and maximum permissible limit (MPL) of World Health Organization (WHO), Bureau of Indian Standard (BIS) and Indian Council of Medical Research (ICMR).

Table 1: Result of the Physical parameters in samples.

\begin{tabular}{|c|c|c|c|c|c|c|c|c|c|}
\hline PARAMETER & \multicolumn{5}{|c|}{ SAMPLING POINT } & WHO & ICMR & BIS & ISI \\
\hline PHYSICAL & $\mathrm{S}_{\mathrm{A}}$ & $\mathrm{S}_{\mathrm{B}}$ & $\mathrm{S}_{\mathrm{C}}$ & $\mathrm{S}_{\mathrm{D}}$ & $\mathrm{S}_{\mathrm{E}}$ & & & & \\
\hline Color & - & - & - & Dusty & - & 5Hazen & - & - & - \\
\hline Odor & - & - & - & - & - & - & - & - & - \\
\hline Taste & - & - & - & - & - & - & - & - & - \\
\hline $\mathrm{pH}$ & 8.15 & 9.15 & 8.62 & 8.92 & 8.45 & $7-8.5$ & $7.0-8.5$ & $7.0-8.3$ & $6.5-8.5$ \\
\hline Conductivity $\left(\times 10^{-3}\right)$ & 0.29 & 0.29 & 0.32 & 0.25 & 0.30 & - & - & - & - \\
\hline T.D.S. (mg/I) & 40 & 20 & 30 & 200 & 90 & 500 & 500 & 500 & 500 \\
\hline $\mathrm{TSS}(\mathrm{mg} / \mathrm{I})$ & 80 & 20 & 40 & 100 & 60 & 500 & - & - & 500 \\
\hline $\mathrm{TH}(\mathrm{mg} / \mathrm{I})$ & 1088 & 48 & 64 & 100 & 120 & 500 & - & - & 300 \\
\hline
\end{tabular}

Key: The sign (-) in $\mathrm{S}_{\mathrm{A}}, \mathrm{S}_{\mathrm{B}}, \mathrm{S}_{\mathrm{C}}, \mathrm{S}_{\mathrm{D}}$, and $\mathrm{S}_{\mathrm{E}}$ signify absent in samples.

Because Well water may be salty, it is full of charged particles, which conducts electricity. The result obtained in the Conductivity investigation showed a low range of conductivity of about 290 microsimens $/ \mathrm{cm}$ compared to the standard of Well and drinking water conductivity which is nearer 821 microsimens/ $\mathrm{cm}$ for West African sub region.

Total Dissolved Solids(TDS) showed a range of 20 to $200 \mathrm{mg} / \mathrm{L}$. The prescribed desirable limit and maximum permissible level are 500 and $2000 \mathrm{mg} / \mathrm{L}$ respectively (WHO, 2003).

For Total Suspended Solid (TSS), sample D was found to have the highest value of $100 \mathrm{mg} / \mathrm{L}$. The presence of suspended solid may cause water to be colored or turbid. Sample D was slightly colored when left to stand for sometime which cleared later with some particles settling at the bottom. The maximum TSS value by WHO and ISI is $500 \mathrm{mg} / \mathrm{L}$. besides sample $\mathrm{D}$, all the other samples fall within permissible limit.

The Total hardness (TH) result obtained is in the range of $48 \mathrm{mg} / \mathrm{L}$ to $1088 \mathrm{mg} / \mathrm{L}$. Sample A was found to have higher value than all other samples. Hardness in water prevents lather formation with soap and increases the boiling point of water depending upon the amount of calcium and magnesium salts in the water. The prescribed limit by ISI and WHO are 300 and $500 \mathrm{mg} / \mathrm{L}$ respectively. Therefore all the samples except sample A are within tolerable limit.

The Chemical Oxygen Demand (COD) value in all five samples varied from $7.6 \mathrm{mg} / 1$ to $51.6 \mathrm{mg} / \mathrm{l}$. The permissible limit of COD for drinking water as prescribed by WHO is $225 \mathrm{mg} / \mathrm{l}$. Therefore all five samples are within tolerable limits.

Table 1: Result of the chemical parameters in samples.

\begin{tabular}{|c|c|c|c|c|c|c|c|c|c|}
\hline PARAMETER & \multicolumn{5}{|c|}{ SAMPLING POINT } & WHO & ICMR & BIS & ISI \\
\hline PHYSICAL & $\mathrm{S}_{\mathrm{A}}$ & $\mathrm{S}_{\mathrm{B}}$ & $\mathrm{S}_{\mathrm{C}}$ & $\mathrm{S}_{\mathrm{D}}$ & $\mathrm{S}_{\mathrm{E}}$ & - & - & - & \\
\hline $\mathrm{COD}(\mathrm{mg} / \mathrm{I})$ & 7.60 & 32.40 & 51.60 & 1.60 & 12.00 & 255 & - & 150 & 150 \\
\hline $\mathrm{NO}_{3}(\mathrm{mg} / \mathrm{I})$ & 6.90 & 15.70 & 3.50 & 1.90 & 6.90 & 5 & - & - & 45 \\
\hline$(\mathrm{Pb})(\mathrm{mg} / \mathrm{I})$ & 0.00120 & 0.07 & 0.010 & 0.022 & 0.010 & 1.0 & - & - & - \\
\hline D.O & 12.10 & 12.50 & 12.60 & 12.40 & 13.00 & - & - & - & 5.0 \\
\hline BOD & 0.60 & 0.70 & 0.70 & 0.70 & 0.60 & - & 6 & - & - \\
\hline
\end{tabular}

Nitratesingroundwater contains are due to leaching with the peculating water. Sewage and other waste rich in nitrates can also contaminate it. The nitrate content in the five samples range from $1.9 \mathrm{mg} / 1$ to $15.70 \mathrm{mg} / \mathrm{l}$ and found to be within the limit. Lead is a cumulative poison to humans and other animals. Therefore high concentration of lead in drinking water is not tolerable. The recommended maximum concentration of lead in drinking water by the World Health Organization (WHO), Indian Standard Institute (ISI) and Bureau of Indian Standard (BIS) is $0.1 \mathrm{ppm}$. From the result obtained, lead present in all the samples is below the prescribed maximum concentration.

Dissolved oxygen is an important parameter in water quality assessment and reflects the physical and biological processes prevailing in the water. The DO value indicates the degree of pollution in water bodies. The ISI recommend minimum value of 5.0 and from the result obtained for all the samples, their DO values are not within the set values. 
Biological oxygen demand (BOD) is a measure of the quality of oxygen used by microorganisms in the oxidation of organic matter. BOD is a measure of quality of dissolved oxygen in $\mathrm{mg} / \mathrm{l}$ necessary for the decomposition of organic matter by microorganisms. From the result obtained, WHO below the minimum values of $6.0 \mathrm{mg} / 1 \mathrm{prescribes}$ the values for all the five samples.

\section{Conclusion And Recommendations}

The result of the study on the Well waters collected from five different wells in Sharada industrial estate shows the water is fit for human for domestic and drinking purposes. However the following are hereby recommended;

1. Wells must be properly treated to get rid of microorganisms and their spores that may be present. This can be cheaply achieved by boiling the Well water before use. Other methods could be filtration, the use of alum for sedimenting suspended solid and the use of disinfectants.

2. The Wells should be constructed with good seal to provide proper covering so as to prevent debris and other waste materials from falling inside which may pollute the water.

3. The Wells should be dug with its walls built with concrete. It should be constructed far away from drainages and pit toilets, which can serve as good source of pollutants.

\section{References}

[1] Baker, R.A., (1964). Effect of Gaseous Aqueous Mixtures of Organic Chemicals.

[2] Baram L. (2007). Evaluating the Environmental Impact of various dietary patterns combined with different food production systems; European Journal of Clinical Nutrition.

[3] Dezuane, J. (1997). Handbook of Drinking Water Quality. Second Ed.

[4] Gleick P. H., Water in Crisis. (1993). A Guide to World Fresh Water Resources,Journal of Minnesota Department of Health (MDH), (2012). Certified Laboratories/Well Water Testing Council.

[5] Kulshreshthra S.N., (1998). A Global Outlook for Water Resources to the year 2025.

[6] U.S Environmental Pollution Agency (EPA) (2000). Guidance for Water Quality, Washington D.C.

[7] U.S. Environmental Protection Agency, 1996, Drinking water regulations and health advisories: EPA 822-B-96-002.

[8] Wolf, H.A., (2004). Environmental impact of Groundwater Quality Overdraft; Selected Case Study in the South Western United States. 